\title{
Relevansi dan Urgensi Kecerdasan Spritual, Intelektual, dan Emosional dalam Perspektif Islam
}

\author{
Amaliyah
}

\section{Universitas Negeri Jakarta}

ikhwanshafa@ymail.com

\begin{abstract}
The formation of a man who is faithful and devoted to God becomes the first and main goal of the implementation of education. The process of forming a faithful and pious human requires several components including input, process and product components. The input components are students' including intelligence, motivation, interests and the others. The process of human formation that believes and cautiously requires spiritual, intellectual and emotional intelligence simultaneously because these three bits of intelligence have interconnected functions and goals. The purpose of this research is to know the differences and similarities between spiritual, intellectual and emotional intelligence, and the relationship between spiritual, intellectual and emotional intelligence in the Islamic perspective. The research findings are the source of intellectual intelligence and emotional intelligence is the spiritual intelligence source of spiritual intelligence is Tauhid, The source of intellectual intelligence and emotional intelligence are logical and phenomenal data. The human structure at the level of the body and soul is called intellectual and emotional intelligence. The human structure at the level of the Spirit/Ruh is called spiritual intelligence
\end{abstract}

Keywords:Relevance, Spiritual intelligence, Intellectual intelligenc, Emotional intelligence, Islamic perspective

\begin{abstract}
Abstrak
Pembentukan manusia yang beriman dan bertakwa kepada Allah, menjadi tujuan utama dan pertama dalam penyelenggaraan pendidikan Islam. Proses untuk membentuk manusia yang beriman dan bertakwa memerlukan beberapa komponen antara lain komponen input, proses dan produk. Komponen input yakni keadaan diri siswa, meliputi kecerdasan, motivasi, minat dan lain-lain. Proses pembentukan manusia yang beriman dan bertakwa membutuhkan kecerdasan spiritual, intelektual dan emosional secara simultan, karena ketiga kecerdasan itu memiliki fungsi dan tujuan yang saling berhubungan. Tujuan penelitian ini adalah mengetahui perbedaan dan persamaan antara kecerdasan spiritual, intelektual dan emosional serta hubungan antara kecerdasan spiritual, intelektual dan emosional dalam perspektif Islam. Hasil temuan penelitian adalah sumber dari kecerdasan intelektual dan kecerdasan emosional, adalah kecerdasan spiritual. Sumber kecerdasan spiritual adalah tauhid. Sumber kecerdasan intelektual dan kecerdasan emosional adalah data logis dan fenomenal. Struktur manusia pada level jasad disebut kecerdasan intelektual dan emosional. Struktur manusia pada level Ruh disebut kecerdasan spiritual
\end{abstract}

Kata Kunci: Relevansi, Kecerdasan spiritual, Kecerdasan intelektual, Kecerdasan emosional, Perspektif islam 


\section{A. Pendahuluan}

Kecerdasan spiritual merupakan dasar intelegensi manusia, hal ini berdasar pada alQur'an surat al-a'raf ayat 171-172, menyatakan bahwa manusia telah diberikan potensi untuk menjalankan prinsip-prinsip tauhid. Keberadaan kecerdasan spiritual menurut pandangan Islam tidak pada alam fisik,oleh karena itu untuk membantu manusia melaksanakan prinsip-prinsip tauhid di alam fisik, maka dimunculkan bentuk kecerdasan lain yakni kecerdasan intelektual dan kecerdasan emosional. Mujib menyatakan bahwa terdapat beberapa bentuk kecerdasan yakni kecerdasan moral, kecerdasan spiritual dan beragama.

Pada hakikatnya bentuk-bentuk kecerdasan spiritual, kecerdasan intelektual dan emosional, berorientasi kepada fitrah manusia yakni memiliki potensi untuk mengimplementasikan prinsip-prinsip tauhid (al-Qur'an surat al-a'raf ayat 171-172).Fungsi dan tujuan kecerdasan intelektual dan kecerdasan emosional untuk memhami prinsipprinsip tauhid dan eksistensi manusia secara internal dan eksternal. Akan tetapi implemetasi kecerdasan intelektual dan emosional cenderung untuk memehami alam fisik saja dan struktur eksternal manusia.

Kecerdasan spiritual, intelektual dan emosional adalah tiga bentuk kecerdasan yang harus diimplementasikan dalam penyelenggaraan pendidikan islam, supaya tujuan hidup dan tujuan pendidikan dapat dicapai, yakni menjadi manusia yang cerdas, sosial dan spiritual. Para ilmuan Islam telah mengkaji berbagai macam potensi yang ada dalam diri manusia, potensi tersebut dapat dikatakan sebagai kecerdasan, akan tetapi pengkajian tidak secara spesifik membahas relevansi, perbedaan serta persamaan tiga kecerdasan yakni kecerdasan intelektual, kecerdasan emosional dan kecerdasan spiritual, maka dibutuhkan penelitian untuk menemukan konsep tentang relevansi, persamaan dan perbedaan tiga keceradasan tersebut dalam persepektif Islam.

\section{B. Metodologi Penelitian}

Pendekatan penelitian yang digunakan dalam penelitian ini adalah pendekatan penelitian kajian pustaka atau library reseach dengan mendeskripsikan berbagai pandangan atau pendapat serta konsep yang terangkum dalam rumusan permasalahan penelitian ini. Data dalam penelitian ini diperoleh dengan metode studi pustaka atau kajian literatur, dan studi dokumen. Data dianalisis dengan teknik analisis data kualitatif, yakni dalam bentuk

${ }^{1}$ Abdul Mujib dan Jusuf Mudzakir, Nuansa-Nuansa Psikologi Islam, (Jakarta: Raya Grafindo Persada, 2002), hh.324-325 
narasi. Proses analisis data meliputi kegiatan reduksi data, pengorganisasian data dan penyajian data.

Desain penelitian, dapat dilihat pada lagkah-langkah di bawah ini:

Diagram 1
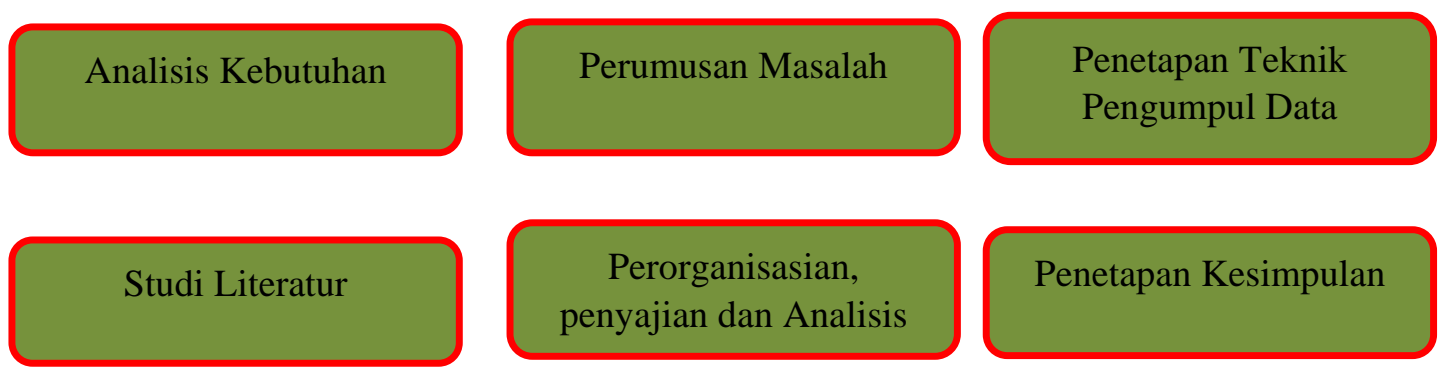

Penetapan Kesimpulan

Desain penelitian

\section{Hasil dan Pembahasan}

\section{Konsep Kecerdasan dalam Persepektif Islam}

Kecerdasan secara etimologi adalah pemahaman, kecepatan dan kesempurnaan dalam memahami sesuatu objek. ${ }^{2}$ Adapun menurut Ibnu Sina kecerdasan adalah kekuatan intuitif. ${ }^{3}$ Bentuk-bentuk kecerdasan terbagi kepada :

a. Kecerdasan intelektual yakni kecerdasan yang berhubungan dengan proses kognitif seperti, berfikir dan lain-lain,

b. Kecerdasan emosional yakni kecerdasan kalbu yang berkaitan dengan pengendalian nafsu-nafsu imfulsif dan agresif,

c. Kecerdasan moral yakni kecerdasan kalbu yang berkaitan dengan hubungan kepada sesame manuasia dan alam,

d. Kecerdasan spiritual yakni kecerdasan kalbu yang erkaitan dengan kualitas psikis atau rohani seseorang,

e. Kecerdasan beragama yakni kecerdasan kalbu yang berhubungan dengan kualitas beragama dan ber-Tuhan.

Kecerdasan spiritual menjadi sesuatu yang baru dan fenomenal dalam kalangan ilmuan barat padahal dalam islam beberapa ilmuan telah mengkaji konsep kecerdasan spiritual hanya belum diaktualisasi dan disosialisasi secara sempurna. Menurut Jalaluddin

2 Abdul Mujib dan Jusuf Mudzakir, Nuansa-Nuansa Psikologi Islam, (Jakarta: Raya Grafindo Persada, 2002), h.317

3 Abdul Mujib dan Jusuf Mudzakir, Nuansa-Nuansa Psikologi Islam, (Jakarta: Raya Grafindo Persada, 2002), h.317 
Rumi kecerdasan spiritual adalah kecerdasan yang didasarkan pada inspirasi Ilahi dan pengetahuan tidak bergerak melalui perubahan dan tidak bertentangan dengan diri manusia ${ }^{4}$. Sementara itu, kecerdasan spiritual menurut Nasr seperti dikutip oleh Suharsono, kecerdasan spiritual adalah suatu bentuk kecerdasan yang berasal dari al-kahmirat alazaliyah (olahan abadi) yakni landasan eksistensi hidup, keberadaan al-khamirat alazaliyah tersembunyi dan akan muncul jika berada dalam kondisi tulus bersih darai berbagai pretensi dan egoism. ${ }^{5}$

Berdasar pada pendapat para ahli maka kecerdasan adalah proses memahami sesuatu objek secara tepat dan cepat. Bentuk objek mengidentifikasi jenis sebuah kecerdasan, objek kecerdasan pada aspek pengetahuan atau ranah kognitif identik dengan kecerdasan intelektual. Objek kecerdasan pada aspek kematangan emosi identik dengan kecerdasan emosional, Objek pada fitrah manusia atau struktur internal manusia identik dengan kecerdasan spiritual.

\section{Hubungan kecerdasan spiritual, kecerdasan intelektual dan kecerdasan emosional}

Kecerdasan spiritual merupakan dasar intelegensi manusia, hal ini didasarkan pada al-Qur'an surat al-a'raf ayat 171-172, manusia memilki fitrah Ilahiah yakni kesanggupan untuk menjalankan prinsip-prinsip tauhid di alam dunia. Keberadaan kecerdasan spiritual tidak pada alam fisik tetapi pada alam metafisik dan telah terdapat dalam diri manusia sejak manusia berada di alam arham, oleh karena itu kecerdasan spiritual perwujudannya sulit dimunculkan jika kondisi manusia cenderung dipengaruhi oleh hawa nafsu dari pada fitrah manusia itu sendiri. Untuk membantu manuasi mengimplementasikan prinsip-prinsip tauhid, maka muncul kecredasan inetelektual dan kecerdasan emosional. Dengan demikian sumber kecerdasan spiritual adalah tatanan Ilahiah, sumber kecerdasan intelektual adalah akal manusia dan sumber kecerdasan emosi adalah kematangan nafs manusia.

Berdasar pada kedudukan atau hirarki kecerdasan dan sumber kecerdasan maka dapat dilihat pada gambar dibawah ini

\footnotetext{
${ }^{4}$ William C,Chittcle, Jalan Cinta Sang Sufi (Yogyakarta: 2001), hh. 36-37

${ }^{5}$ Suharsono, Mencerdaskan Anak, (Jakarta:Inisiasi Press, 2001), h.61
} 


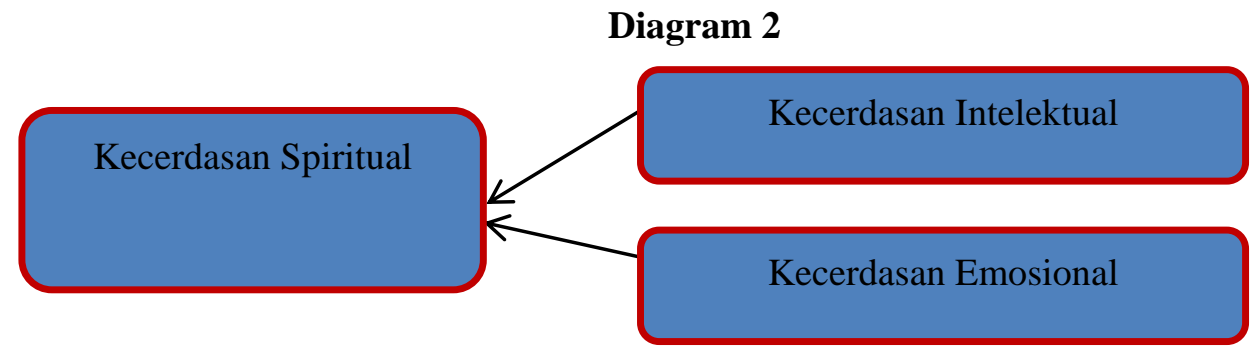

\section{Hirarki kecerdasan dan sumber kecerdasan}

Berdasar pada gambar tersebut maka untuk mencapai atau memperoleh kecerdasan spriritual manusia memerlukan kecerdasan intelektual dan kecerdasan emosional yakni menggunakan akal dan menggunakan kematangan emosi untuk menerapkan prinsip-prinsip tauhid secara tepat dan sempurna sehingga tujuan akhir dari kehidupan di dunia yakni bertemu dengan Ruh Ilahiah akan tercapai. Dengan demikian hubungan antara kecerdasan spiritual, intelektual dan emosial adalah sebagai alat untuk memehami prinsip-prinsip tauhid, proses untuk memehami prinsip-prinsip tauhid dilakukan secara bertahap yakni melaui jism (tubuh) manusia, tahap kedua melalui nafs dan terakhir adalah ruh.

\section{Perbedaan dan persamaan kecerdasan spiritual, kecerdasan intelektual dan kecerdasan emosional}

Perbedaan antara kecerdasan spiritual, intelektual dan emosional dapat dilihat dari sumber inspirasi, teknik memahami objek dan pemahaman akan jatidiri manusia itu sendiri. Kecerdasan spiritual sumbernya berasal dari tatanan ilahiah. Kecerdasan intelektual dan emosioanal sumbernya adalah pada tatanan logis dan fenomenal. Kecerdasan spiritual merupakan teknik dalam memahami objek tidak hanya bersifat kuantitatif dan fenomenal tetapi pada tatanan epistemik dan ontologi. Kecerdasan intelektual dan emosional teknik memahami objek dalam tatanan kuantitatif yakni data dan fakta, ${ }^{6}$ Perbedaan ketiga yakni tentang pemahamanm diri manusia, kecerdasan spiritual memahami aspek akan jatidiri manusia sampai pada tataran noumenal yakni struktur internal manusia. Adapun kecerdasan intelektual dan emosional memahami aspek jati diri manusia hanya sampai pada aspek psikologis, kognitif, psikomotorik dan sosial.

Persamaan antara kecerdasan spiritual, intelektual dan emosional yakni sebagai alat untuk memehami dan mengimplementasikan prinsip-prinsip tauhid. Selain itu tujuan dan fungsi dari tiga kecerdasan tersebut adalah sama yakni mencari dan mewujudkan kebenaran

\footnotetext{
${ }^{6}$ Suharsono, Melejitkan IQ,IE dan IS, (Jakarta:Inisiasi Press, 2002), h. 139
} 
Kecerdasan intelektual adalah kecerdasan yanga berkaitan dengan penerimaan dan pembenaran pengetahuan yang berdasarkan pada akal manusia serta fakta dan data. sementara itu kecerdasan emosional adalah kecerdasan yang berkaitan dengan pengendalian nafsu impulsive dan nafsu agresif. Kecerdasan spiritual adalah kecerdasan kalbu yang berkaitan dengan kualitas rohani seseorang.

\section{Struktur Manusia dalam Persepektif Islam}

Struktur manusia dalam kajian literatur ilmuan Barat, terdiri dari soul, spirit, heart, mind dan intellect. Sementara itu, Struktur manusia dalam pandangan Islam mengandung tiga aspek yakni nafs, ruh dan jasad. Nafs dalam Islam terbagi nafs al-hewaniyyah, nafs al-ammarah, nafs al-lawwamah (menyadari kekurangan diri) dan terakhir adalah nafs almuthma'innah (jiwa yang damai). Istilah nafs sering dikacaukan dengan istilah hawa nafsu dalam kajian bahasa Indonesia. Pengertian hawa dalam kajian Islam adalah memilki wujud dan hakikat tersendiri. Aspek hawa berpasangan dengan syahwat. Hawa bersifat non material, seperti harga diri dan hal lain yang bersifat abstrak, sedangkan syahwat bersifat material dan bersumber pada jasad insan yang wujudnya sudah disusun berdasarkan unsurunsur material bumi ${ }^{7}$. Nafs adalah perantara antara jiwa rasional (ruh) dengan jism (badan). Nafs bersifat seperti tanah dan kemanusiaan, sedangkan ruh bersifat seperti cahaya dan bersifat ketuhanan ${ }^{8}$

Ruh dalam struktur manusia berada pada inti jiwa manusia. Konsep Ruh Al-Quds dalam Al-Qur'an identik dengan konsep holy spirit dalam bible. Ruh Al-Quds berkedudukan di alam jabarut sedangkan Ruh al-amin berkedudukan di alam malakut. Ruh Al-Quds bernisbat kepada martabat Ilahi. ${ }^{9}$ Ruh berbeda dengan nyawa, ruh bersifat substansi yakni hanya dapat dimilki oleh manusia sedangkan nyawa menurut al-Ghazali nyawa adalah ruh material, kebradaan nyawa tidak hanya pada manusia tetapi terdapat pula pada hewan $^{10}$

Ruh terbagi dua yakni ruh al-munazzalah dan ruh al-gharizah. Ruh al-munazzalah berdiri pada zatnya sendiri dan diciptakan di alam ruh. Ruh ini dapat diinterpretasikan sebagai fitrah manusia. Aktualisasi dari ruh al-munazzalah adalah amanah yakni

${ }^{7}$ Zamzam, A, Jamaluddin T dan Tri Boedi Hermawan, 'Struktur Insan Dalam Al-qur'an”, Makalah (Bandung: Paramartha International for Tashawwuf Studies (PITCS), 2001), h. 4

${ }^{8}$ Zamzam, A, Jamaluddin T dan Tri Boedi Hermawan, 'Struktur Insan Dalam Al-qur'an”, Makalah (Bandung: Paramartha International for Tashawwuf Studies (PITCS), 2001), h. 24

9 Zamzam, A, Jamaluddin T dan Tri Boedi Hermawan, 'Struktur Insan Dalam Al-qur'an”, Makalah (Bandung: Paramartha International for Tashawwuf Studies (PITCS), 2001), h. 5

${ }^{10}$ Abdul Mujib dan Jusuf Mudzakir, Nuansa-Nuansa Psikologi Islam, (Jakarta: Raya Grafindo Persada, 2002), h.40 
penerimaan kesaksian manusia terhadap prinsip-prinsip ketuhanan pada waktu di alam arwah. ${ }^{11}$ Adapun ruh al-gharizah adalah bagian dari ruh manusia yang berhubungan dengan jasad.

Jasad adalah substansi manusia yang terdiri dari organ tubuh manusia. Jasad manusia terdiri dari udara, tanah, api dan air. Keempat unsur ini merupakan materi yang mati, menurut Ikhwan al-shafa materi yang mati akan diberi daya dan tanda oleh nafs. ${ }^{12}$ Jasad manusia bersifat duniawi dan memiliki bentuk, rupa, berkualitas, bergerak, diam dan terdiri dari beberapa organ tubuh. Perbedaan antara ruh, jasad dan nafs dapat dilihat pada tabel 2 di bawah ini: ${ }^{13}$

Tabel 1

\begin{tabular}{|l|l|l|}
\hline \multicolumn{1}{|c|}{ Substansi Ruh } & \multicolumn{1}{|c|}{ Substansi Jasad } & \multicolumn{1}{c|}{ Substansi Nafs } \\
\hline Alam arwah & Alam dunia & Alam dunia dan ruhani \\
\hline $\begin{array}{l}\text { Tidak memilki bentuk, } \\
\text { rupa dan kadar }\end{array}$ & $\begin{array}{l}\text { Memilki bentuk, rupa dan } \\
\text { kadar }\end{array}$ & $\begin{array}{l}\text { Antara memilki dan tidak } \\
\text { memiliki bentuk, rupa } \\
\text { dan kadar }\end{array}$ \\
\hline Cenderung kepada tauhid & Cenderung kepada syahwat & $\begin{array}{l}\text { Cenderung kepada baik dan } \\
\text { buruk }\end{array}$ \\
\hline Memilki energy al amanah & Memiliki energy jasmaniah & $\begin{array}{l}\text { Memiliki energy jasmaniah } \\
\text { dan ruhani }\end{array}$ \\
\hline $\begin{array}{l}\text { Eksistensinya memotivasi } \\
\text { kehidupan dunia }\end{array}$ & $\begin{array}{l}\text { Eksistensinya menjadi } \\
\text { wadah ruh }\end{array}$ & $\begin{array}{l}\text { Eksistensinya aktualisasi } \\
\text { atau realisasi diri }\end{array}$ \\
\hline Substansi abadi & $\begin{array}{l}\text { Substansi temporer dan } \\
\text { hancur setelah kematian }\end{array}$ & $\begin{array}{l}\text { Berada antar abadi dan } \\
\text { hancur }\end{array}$ \\
\hline
\end{tabular}

Perbedaan antara ruh, jasad dan nafs

Berdasar pada keadaan struktur manusia yakni jasad, nafs dan ruh, maka kecerdasan intelektual dan kecerdasan emosional berada struktur jasad atau jism, jika dikaitkan dengan kegiatan pembelajaran, maka jasad manusia sebagai subjek atau pelaku atas pelaksana prinsip-prinsip tauhid, sedangkan nafs jika dikaitkan dengan kegiatan pembelajaran maka nafs adalah sebagim objek yakni sebagai sesuatu yang harus dikendalikan. Ruh jika dikaitkan dengan kecerdasan dan kegiatan pembelajaran maka ruh berkedudukan sebgai tujuan inti dan akhir pada semua aspek kehidupan di dunia, dengan

11 Abdul Mujib dan Jusuf Mudzakir, Nuansa-Nuansa Psikologi Islam, (Jakarta: Raya Grafindo Persada, 2002), h. 44

12 Abdul Mujib dan Jusuf Mudzakir, Nuansa-Nuansa Psikologi Islam, (Jakarta: Raya Grafindo Persada, 2002), hh. 40-41

13 Abdul Mujib dan Jusuf Mudzakir, Nuansa-Nuansa Psikologi Islam, (Jakarta: Raya Grafindo Persada, 2002),, h. 47 
demikian kecerdasan spiritual berada pada struktur manusia yakni ruh dan untuk mencapai kecerdasan spiritual manusia memerlukan jasad yakni kecerdasan intelektual dan emosional serta harus memilki nafs yang suci. Dengan kata lain manusia jika ingin mencapai kecerdasan spiritual atau struktur manusia yang tertinggi yakni ruh, maka harus mampu melewati tahap-tahap nafs yakni al-hewaniyyah, nafs al-ammarah, nafs allawwamah (menyadari kekurangan diri) dan terakhir adalah nafs al-muthma'innah (jiwa yang damai)

\section{Struktur Manusia dalam Mengaktualkan Kecerdasan Spritual}

Kecerdasan spiritual dalam pandangan Islam adalah suatu bentuk kesadaran manusia untuk mengaktualkan prinsip-prinsip tauhid yang telah ditanamkan dalam jiwa manusia sejak di alam arwah. Proses untuk mengaktualkan kecerdasan spiritual dilakukan melalui struktur manusia baik eksternal maupun internal. Dalam dunia tasawuf objek pengaktualan kecerdasan spiritual adalah nafs, jika manusia telah mencapai stuktur nafs muthmainnah, maka manusia akan mencapai struktur tertinggi manusia yakni ruh.

Manusia pada dasarnya sudah memilki potensi untuk menjadi manusia yang sempurna, hal ini sesuai dengan teori psikologi pendidikan yakni teori tabularasa, "manusia bukan sebuah kertas putih atau botol kosong" dengan kata lain manusia sudah mempunyai suatu bekal atau kemampuan untuk menjadi manusia sempurna. Alam dunia adalah tempat manusia mengimplementasikan potensi yang diberikan Tuhan di alam arwah. Proses untuk mengaktualisasikan potensi tersebut memerlukan nafs dan jasad. Tahap awal pengaktulisasian dimulai dari proses mengendalikan syahwat dan hawa nafsu, keduanya berada pada struktur manusia yakni kalbu atau hati dan ego yakni akal. Manusia harus mengupgrade hati dan akalnya supaya tidak dikendalikan oleh syahwat dan hawa nafsu. Ketika manusia tidak bisa mengendalikan ego (akal) atau lepas kendali dari hati, maka nafs akan dikendalikan oleh hawa nafsu dan syahwat, sebaliknya jika ego dan hati dapat dikendalikan maka nafs tidak dapat dikendalikan oleh hawa dan syahwat.

Hal ini dapat dilihat pada gambar proses mengaktualkan kecerdasan spiritual, intelektual dan emosi dalam struktur manusia: 


\section{Gambar 1}

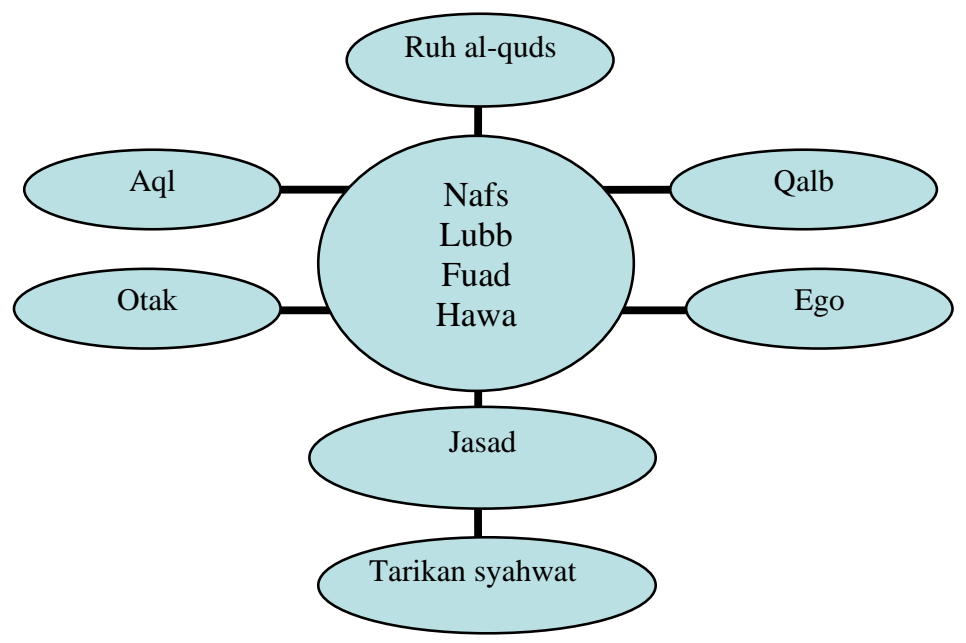

Proses mengaktualkan 3 kecerdasan

Berdasar pada gambar di atas, kecerdasan spiritual adalah puncaknya kecerdasan dan proses aktualisasi kecerdasan spiritual adalah kemampuan mengendalikan hawa dan syhwat yang berada pada otak dan ego yakni pada struktur jasad, kemudian mengendalikan nafs yang berada pada struktur akal dan hati. Dengan demikian kecrdasan intelektual dan emosional memilki tugas untuk mengendalikan struktur otak, ego (jasad)sesuai prinsipprinsip tauhid lalu mengendalikan nafs (akal dan hati atau qalb) sesuai prinsip-prinsip tauhid hasilnya akan sampai pada kecerdasan spiritual yang berda pada struktur tertinggi manusia yakni Ruh.

\section{Penutup}

Hirarki kecerdasan dalam perspektif islam adalah paling rendah kecerdasan intelektual dan emosional. Kecerdasan paling tinggi dan sumber dari kecerdasan adalah kecerdasan spiritual. Setiap struktur manusia memilki tugas untuk mengendalikan jasad dan nafs. Faktor-faktor penghambat mencapai struktur manusia yang tertinggi adalah hawa dan syahwat. Pengendalian jasad dan nafs supaya tidak didominasi hawa dan syahwat, maka membutuhkan kecerdasan intelektual dan kecerdasan emosianal yang mengacu atau memiliki sebuah kurikulum kehidupaan dunia dan akhirat yakni prinsip-prinsip tauhid.

Penyelenggara pendidikan khususnya pendidikan Islam, menitik beratkan pada semua kecerdasan yakni kecerdasan intelektual, emosional dan menerapkan prinsipprinsip tauhid pada semua mata pelajaran atau mata kuliah, misalnya pembelajaran fisika maka materi tidak hanya sebatas data dan fakta tetapi memuat prinsip-prinsip tauhid, supaya struktur manusia dapat dikendaikan dengan sempurna. 


\section{E. Daftar Pustaka}

Abidin Zainal, Filsafat Manusia, Bandung: Rosda Karya, 2000

Bayrakli, Bayraktar, Eksistensi Manusia (terj), Jakarta: Parenial Press, 2000

Chitik, William.C, Jalan Cinta Sang Sufi, Ajaran-Ajaran Spiritual Jalaluddin Rumi, Yogyakarta: Qoalam, 2001

Mahzar, Armahedi," Telaah Kritis Tentang Kecerdasan Spritual Danah Zohar", Bandung: PCTIS, 2001

Mujib, Abdul dan Jusuf Mudzakir, Nuansa-Nuansa Psikologi Islam, Jakarta: Raja Grafindo Persada, 2002

Nasr, Sayyed Hossein, Dasar-Dsar Spiritual Islam (terj), Bandung: Mizan, 2002

Nataatmadja Hidayat, Intelegensi Spiritual Jakarta: Intuisi Press, 2003

Pasiak Taufik, Revolusi IQ/EQ/SQ, Bandung: Mizan, 2002

Suharsono Mencerdaskan Anak, Jakarta: Inisiasi Press, 2000

Melejitkan IQ,IE,IS, Jakarta: Inisiasi Press, 2002 